\title{
A Kinetic Study on the Preparation of AlNi Alloys by Aluminothermic Reduction of NiO Powders
}

\author{
Cesar Silva Beltran ${ }^{1}$, Alfredo Flores Valdes ${ }^{1}$, Jesús Torres Torres ${ }^{1}$ and Rocio Ochoa Palacios ${ }^{2, *}$ \\ 1 Centro de Investigación y de Estudios Avanzados del IPN, Unidad Saltillo Avenida Industria \\ Metalúrgica 1062, Parque Industrial Saltillo-Ramos Arizpe, 25900 Ramos Arizpe, Coahuila, Mexico; \\ slash_sil@hotmail.com (C.S.B.); alfredo.flores@cinvestav.edu.mx (A.F.V.); \\ jesus.torres@cinvestav.edu.mx (J.T.T.) \\ 2 Instituto Tecnológico de México, Campus Saltillo, Venustiano Carranza, 25000 Saltillo, Coahuila, Mexico \\ * Correspondence: rochoa@itsaltillo.edu.mx; Tel.: +52-844-438-9500
}

Received: 9 July 2018; Accepted: 31 July 2018; Published: 28 August 2018

\begin{abstract}
In this work, the experimental results obtained during the preparation of $\mathrm{Al}-\mathrm{Ni}$ and Al-Ni-Mg alloys using the aluminothermic reduction of $\mathrm{NiO}$ by submerged powder injection, assisted with mechanical agitation are presented and discussed. The analyzed variables were melt temperature, agitation speed, and initial magnesium concentration in the molten alloy. For some of the experiments performed, it was found that the Ni concentration increased from 0 to about $3 \mathrm{wt}-\%$ after $90 \mathrm{~min}$ of treatment at constant temperature and constant agitation speed. In order to determine the values of the kinetic parameters of interest, such as the activation energy and the rate constants, the values of the results obtained were fitted to the kinetic formulae available. Moreover, the kinetics of the reaction were found to be governed by the diffusion of $\mathrm{Al}$ and $\mathrm{Mg}$ to the $\mathrm{NiO}$ boundary layer, where $\mathrm{MgAl}_{2} \mathrm{O}_{4}$ or $\mathrm{Al}_{2} \mathrm{O}_{3}$ were formed as the main reaction products. Finally, from a thermodynamic study of the system, the main reactions that took place are explained.
\end{abstract}

Keywords: Al-Ni alloys; aluminothermic reactions; reaction rate; $\mathrm{Al}$ master alloys; kinetics

\section{Introduction}

Aluminum-nickel alloys are widely used in the manufacturing of parts for the automotive industry, particularly those with a high nickel content, around $3 \mathrm{wt}-\%$, and in cutting tools with TiAl because of their high resistance and low corrosion [1-4]. It is expected that in the upcoming years, the production of this type of alloy will increase worldwide, to reach a level of production higher than 400,000 tons per year. The possibility of preparing $\mathrm{Al}-\mathrm{Ni}$ and $\mathrm{Al}-\mathrm{Ni}-\mathrm{Mg}$ alloys from the aluminothermic reduction of $\mathrm{NiO}$ has been proposed, using the submerged injection of powders as a technique for incorporating the nickel oxide particles.

In this sense, the first applications of the aluminothermic reduction of oxides were in the preparation of molten iron streams for filling the enclosures of exposed surfaces, where the slag rich in $\mathrm{Al}_{2} \mathrm{O}_{3}$ could be separated easily because of its lower density relative to that of iron [5]. Currently, an aluminothermic reduction is used for the preparation of aluminum master alloys, such as $\mathrm{Al}-\mathrm{Sr}-\mathrm{Mg}$, $\mathrm{Al}-\mathrm{Ce}-\mathrm{Mg}$, Al-Zn, Al-Mn, Al-Zr, Al-Mg-Fe-Cr, Al-Li, and so on. [6-15]. Nowadays, aluminothermic reduction is the most common practice used in the production of both kinds of products, pure metals or alloys [16-19]. However, only recently has the understanding of the kinetics of reaction been addressed for the systems of reaction, as every system is quite different.

The reduction reaction of nickel oxide by molten aluminum has a considerably negative value for the standard Gibbs free energy of reaction at operating temperatures, as is shown by the next reaction:

$$
3 \mathrm{MO}+2 \mathrm{Al}=\mathrm{Al}_{2} \mathrm{O}_{3}+3 \mathrm{M}
$$


In the specific case of $\mathrm{NiO}$, it is possible to accelerate the reduction reaction of nickel oxide with magnesium, thereby increasing its concentration in the molten aluminum during the aluminothermic process. In this case, the aluminothermic reaction occurring at $1073 \mathrm{~K}$ could be as follows:

$$
2 \mathrm{Al}+\mathrm{Mg}+4 \mathrm{NiO}=\mathrm{MgAl}_{2} \mathrm{O}_{4}+4 \mathrm{Ni}, \Delta G^{\circ} 1073 \mathrm{~K}=-869.48 \mathrm{~kJ}
$$

Magnesium enhances the reaction rate, not only through its effect on the chemical reactivity of the molten bath, but also through its effect on the surface tension of molten aluminum, improving the wettability between the $\mathrm{NiO}$ particles and the molten aluminum solution [20].

On the other hand, it is broadly known that in the last 30 years, a lot of polluting waste from secondary spent batteries has been generated, of which $\mathrm{NiO}$ and nickel hydroxide $(\mathrm{NiOH})$ are the main components. As such, it is attractive to investigate the aluminothermic reduction rate of $\mathrm{NiO}$ to formulate and propose alternatives for the use of materials that come from the recycling industry, and that can have a high added value, such as the preparation of Al-Ni or Al-Ni-Mg type alloys. In this sense, the main purpose of this paper is to present and discuss the results of an investigation aimed at understanding the role of temperature, initial magnesium concentration in molten aluminum, and the degree of agitation during the preparation of $\mathrm{Al}-\mathrm{Ni}$ and $\mathrm{Al}-\mathrm{Ni}-\mathrm{Mg}$ alloys using a submerged powder injection of $\mathrm{NiO}$ powders, assisted by mechanical agitation. The results mainly focus on measuring the reaction rate and values of some of the kinetic parameters of interest, such as the rate constants and activation energy values of the process, where describing the mechanism of the reaction is of paramount importance.

\section{Materials and Methods}

A 70 KW Power Track 75-30 electromagnetic medium frequency induction furnace, equipped with a silicon carbide crucible with a capacity of $10 \mathrm{~kg}$ of molten aluminum, was used as the melting unit. The powder injection equipment, whose scheme is presented in Figure 1, allowed for the continuous and controlled feeding of the solid material $(\mathrm{NiO})$ through an inert carrier gas, which in this investigation, was high purity argon (99.99\%). The design of the powder injection equipment used for the tests basically consisted of a pressurized chamber, inside which was a cylindrical container to deposit the reactive powder. This container was provided with a worm on the inside, which was rotated by an electric motor connected to a voltage controller located on the control board. This allowed us to vary the speed of rotation of the worm, and therefore, control the speed of the feeding of the powder.

The mixture of powder/gas falls directly into a funnel that connected the feeding line to the outlet lance of the pressurized system, being dragged thereto by means of the carrier gas. In this way, a powder/gas mixture is conducted towards the melting unit, where it is injected inside the molten metal through a graphite lance. This lance is located at a depth of $85 \%$ of the height of the molten metal. The location of the injection lance with respect to the geometry of the furnace, plays a very important role in the reaction kinetics, facilitating the discharge of the powder, therefore assuring its contact with the molten metal solution. The dimensions of this lance were as follows: length, $50 \mathrm{~cm}$; external diameter, $5.08 \mathrm{~cm}$; and diameter of the internal hole, $3.54 \mathrm{~cm}$. To promote a better agitation inside the furnace, a graphite agitator was built, which was assembled to a mechanical drill and placed in the center of the bath; in this way, the agitation was constant and vigorous, as, in addition to the agitator and the gas injected, the Eddy electromagnetic waves generated by the induction coil helped to reach a greater efficiency in the mixing conditions. An insulating lid was attached to the furnace to minimize the inlet of air to the furnace. This stage had an entry for the mechanical agitator and another for the injection lance. 


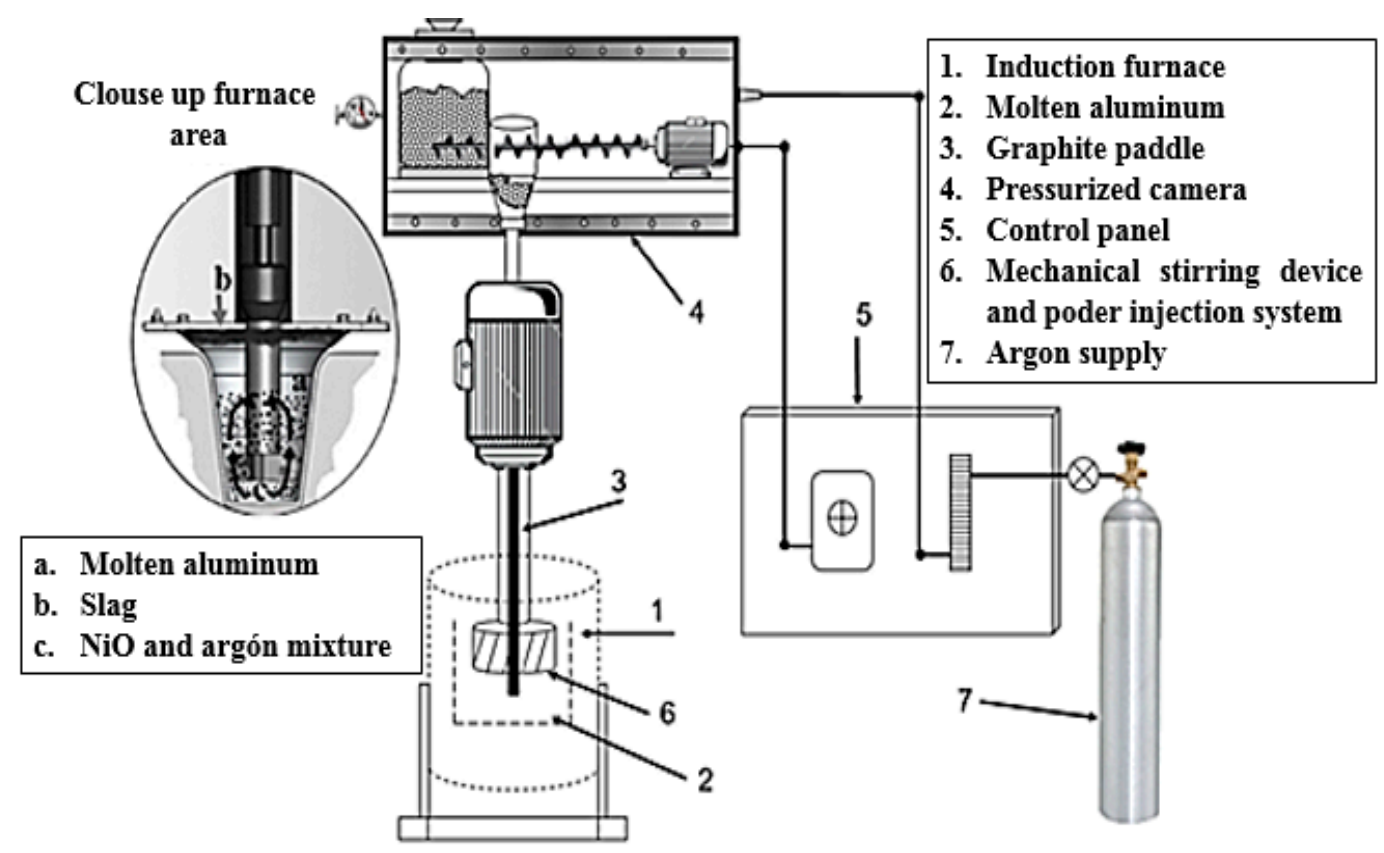

Figure 1. Schematic illustration of the experimental set-up employed in the experiments of the submerged powder injection with mechanical agitation.

Once the lid and the agitator were placed, the temperature and the revolutions per minute were adjusted while the lance was inserted in the molten aluminum to later adjust the powder feeding speed, thus initiating the treatment. We conducted 27 experiments, where the effects of temperature, percentage of magnesium in the alloy, and agitation speed in the molten bath were investigated. The operational parameters and their values were selected from preliminary works [8-12], where the kinetics of the aluminothermic reactions have been studied, not only for attaining reliable reaction efficiencies, but also to avoid metal losses during treatment. Initially, a factorial design was proposed to reduce the experimental errors. The factorial design was comprised of three factors and three levels, as is shown in Table 1. The number of experiments was performed according to the data in Table 1 and Equation (3).

Table 1. Parameters and levels of the initial experimental design.

\begin{tabular}{cccc}
\hline \multirow{2}{*}{ Factors } & \multicolumn{3}{c}{ Level } \\
\cline { 2 - 4 } & $\mathbf{1}$ & $\mathbf{2}$ & $\mathbf{3}$ \\
\hline Temperature (K) & 1023 & 1073 & 1123 \\
Mg (wt- $\%)$ & 0 & 2 & 3 \\
Agitation (rpm) & 50 & 100 & 300 \\
\hline
\end{tabular}

$$
N=a \times b \times c \times n
$$

where $N=$ numbers of experiments; $a=3$ (factor A levels) A level; $b=3$ (factor B levels) B level; $c=3$ (factor $\mathrm{C}$ levels) $\mathrm{C}$ level; and $n=1$ (number of replicas).

According to this, the total number of experiments $\left(E_{i}\right)$ is shown in Table 2. To calculate the number of reagents to be injected, the amount of aluminum, the nickel amount released from $\mathrm{NiO}$, and the stoichiometry given by Reaction (2) were considered. Therefore, the amount of theoretical $\mathrm{NiO}$ that could feasibly be added to the molten bath was calculated as $250 \mathrm{~g}$, also by considering the magnesium concentration in the corresponding trial tests that required it. The target $\mathrm{Ni}$ concentration was $3 \mathrm{wt}-\%$. The parameters that remained constant were the initial quantity of molten aluminum, 
$5 \mathrm{~kg}$; powder injection rate, $250 \mathrm{~g} \mathrm{~min}^{-1}$ of $\mathrm{NiO}$; argon injection rate, $5 \mathrm{~L} \mathrm{~min} \mathrm{~m}^{-1}$; and particle size of the $\mathrm{NiO}$ powders, to the order of a $4 \mu \mathrm{m}$ average.

Table 2. Design of total experiments $\left(E_{i, j, k}\right) . i$-temperature $(\mathrm{K}) ; j$-initial Mg concentration (wt- $\left.\%\right)$; $k$-agitation speed (rpm).

\begin{tabular}{ccccc}
\hline E1 & E2 & E3 & E4 & E5 \\
$1023,0,50$ & $1023,0,100$ & $1023,0,300$ & $1073,2,50$ & $1073,2,100$ \\
\hline E6 & $E 7$ & $E 8$ & $E 9$ & E10 \\
$1073,2,300$ & $1073,3,50$ & $1073,3,100$ & $1073,3,300$ & $1073,0,50$ \\
\hline$E 11$ & $E 12$ & $E 13$ & $E 14$ & E15 \\
$1073,0,100$ & $1073,0,300$ & $1073,2,50$ & $1073,2,100$ & $1073,2,300$ \\
\hline$E 16$ & $E 17$ & $E 18$ & $E 19$ & $E 20$ \\
$1073,3,50$ & $1073,3,100$ & $1073,3,300$ & $1123,0,50$ & $1123,0,100$ \\
\hline$E 21$ & $E 22$ & $E 23$ & $E 24$ & $E 25$ \\
$1123,0,300$ & $1123,2,50$ & $1123,2,100$ & $1123,2,300$ & $1123,3,50$ \\
\hline$E 26$ & $E 27$ & & & \\
$1123,3,100$ & $1123,3,30$ & & & \\
\hline
\end{tabular}

Samples from the molten bath were taken every $10 \mathrm{~min}$, attaining up to 90 min of treatment. These samples were poured into a metallic mold and marked accordingly for chemical analysis determinations and microscopic observations, using both optical and scanning electron microscopy (SEM). The response variables were the actual nickel and magnesium concentrations, and the amount of $\mathrm{Ni}$ or $\mathrm{Ni}-\mathrm{Mg}$ rich phases as a function of the injection time. A chemical analysis was carried out using the spark emission spectrometry technique. The chemical composition of the aluminum alloy is given in Table 3, while the chemical composition of the $\mathrm{NiO}$ powders is given Table 4 .

Table 3. Chemical composition of the aluminum alloy (wt-\%).

\begin{tabular}{cccccccccccc}
\hline Element & $\mathbf{S i}$ & $\mathbf{F e}$ & $\mathbf{C u}$ & $\mathbf{M n}$ & $\mathbf{M g}$ & $\mathbf{C r}$ & $\mathbf{N i}$ & $\mathbf{Z n}$ & $\mathbf{S n}$ & $\mathbf{T i}$ & Al \\
\hline wt $\%$ & 0.013 & 0.48 & 0.025 & 0.012 & 0.089 & 0.0012 & 0.0003 & 0.021 & 0.013 & 0.0012 & 99.34 \\
\hline
\end{tabular}

Table 4. Chemical composition of the $\mathrm{NiO}$ powders (wt- $\%$ ).

\begin{tabular}{cccccccccccc}
\hline Element & $\mathbf{N i}$ & $\mathbf{C o}$ & $\mathbf{F e}$ & $\mathbf{C u}$ & $\mathbf{Z n}$ & $\mathbf{M n}$ & $\mathbf{M g}$ & $\mathbf{C a}$ & $\mathbf{N a}$ & $\mathbf{S}$ & $\mathbf{O}$ \\
\hline${ }_{\mathrm{wt}} \mathrm{\%} \%$ & 76.39 & 0.02 & 0.005 & 0.001 & 0.007 & 0.02 & 0.01 & 0.009 & 0.004 & 0.06 & 23.45 \\
\hline
\end{tabular}

At the end of each experiment, the samples from the produced slags were taken for characterization by X-ray diffraction. To determine the Standard Gibbs free energy of reaction, the software HSC [21] was used, while for the drawing diagrams of the phase stability as a function of the temperature of the reaction, the software Factsage Chemistry Software was used [22].

\section{Results and Discussion}

\subsection{Experimental Results}

Figures 2 and 3 show that the Ni concentration increased in the molten alloys as a function of the injection time for the temperatures and initial magnesium concentrations indicated, at the agitation speed of $300 \mathrm{rpm}$. From these graphs, the nickel concentration reached the highest value at higher magnesium concentrations, at the temperature of $1123 \mathrm{~K}$. 


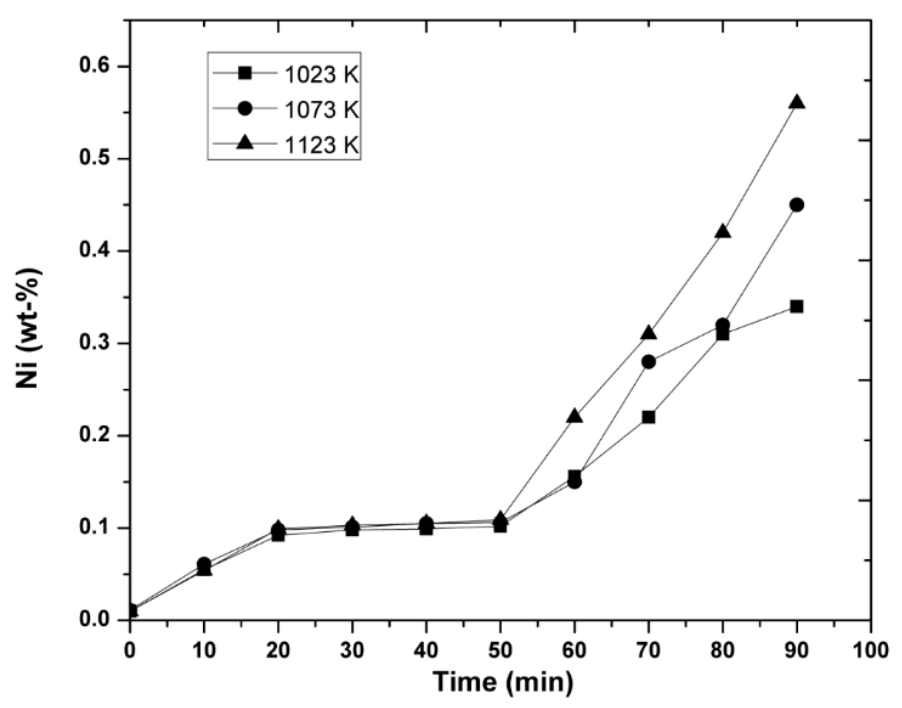

Figure 2. Increase in nickel concentration as a function of injection time at the indicated temperatures, for $0 \mathrm{wt}-\% \mathrm{Mg}$, and a constant agitation speed of $300 \mathrm{rpm}$.

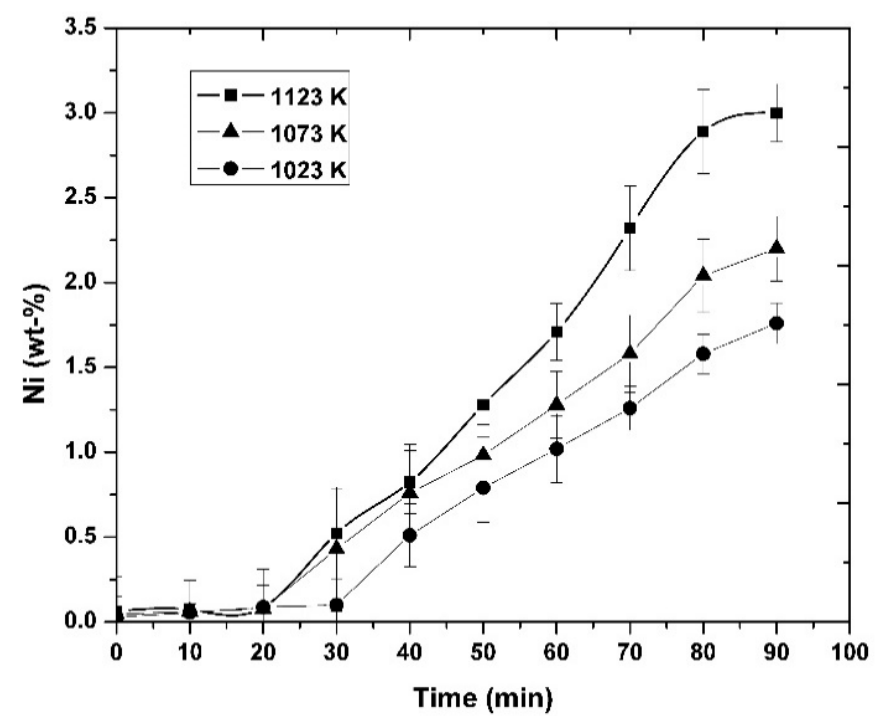

Figure 3. Increase in the nickel concentration as a function of injection time at the indicated temperatures for $3 \mathrm{wt}-\% \mathrm{Mg}$ content in the alloy and at a constant agitation speed of $300 \mathrm{rpm}$.

Figure 4 shows the increase in the Ni concentration as a function of the injection time for the agitation speeds considered, at the constant initial $\mathrm{Mg}$ concentration and temperature indicated. From this figure, it can be observed how the agitation speed plays an important role in the aluminothermic reduction of the $\mathrm{NiO}$ particles, which was due to the improved mass transfer conditions attained at higher values of this parameter. Indirectly, it also indicated the diffusive nature of the process taking place. 


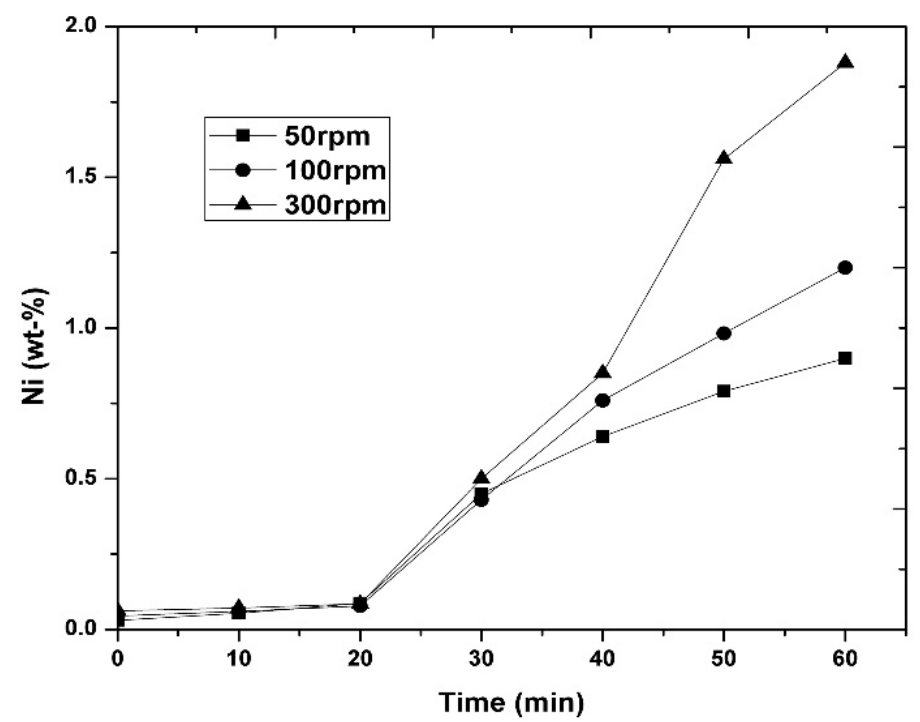

Figure 4. Increase in the nickel concentration as a function of injection time, at the indicated agitation speeds, for an initial $\mathrm{Mg}$ concentration of $3 \mathrm{wt}-\%$, and a temperature of $1123 \mathrm{~K}$.

From the explanations of Guedes et al. [23], the increase in the nickel concentration as a function of the injection time, as shown in Figures 2 and 3, can be explained as follows. When magnesium is not present in the molten alloy, a layer of $\mathrm{Al}_{2} \mathrm{O}_{3}$ is formed at the beginning of the $\mathrm{NiO}$ reduction reaction. The growth of this layer minimizes the contact between the molten aluminum and the reaction front, acting as a barrier between both the aluminum and nickel oxide, which prevents the reaction given by Equation (2) to be completed. However, the $\mathrm{Al}_{2} \mathrm{O}_{3}$ layer is not completely impervious, thus having some porosity through which the aluminum can diffuse to the boundary layer, where it reaches the surface of the $\mathrm{NiO}$ particles. Magnesium improves the reaction rate in two ways. At $973 \mathrm{~K}$, it reduces the surface tension of the molten aluminum from 0.91 (with no $\mathrm{Mg}$ present) to $0.66 \mathrm{~N} \mathrm{~m}^{-1}$ for a magnesium concentration equal to $1 \mathrm{wt}-\%$ [24]. This facilitates the wettability of the $\mathrm{NiO}$ particles in the molten phase. On the other hand, $\mathrm{Mg}$ increases the reactivity of the bath, because this element also reduces the $\mathrm{NiO}$ to $973 \mathrm{~K}$, according to Reaction (2), where the greater negative value of its Gibbs free energy indicates the spontaneity of this reaction.

During their experiments on the synthesis of the $\mathrm{Al} / \mathrm{Al}_{2} \mathrm{O}_{3}$ composites, Pai and Ray [25] found that $\mathrm{MgO}$ could be formed from the reduction of $\mathrm{Al}_{2} \mathrm{O}_{3}$ by the magnesium contained in the alloy. This reduction reaction can also occur in the case of the $\mathrm{NiO}$ reduction reaction given by Equation (2). In turn, $\mathrm{MgO}$ and $\mathrm{Al}_{2} \mathrm{O}_{3}$ can react during solidification to form $\mathrm{MgAl}_{2} \mathrm{O}_{4}$ as the final reaction product, according to the following reaction between pure compounds, whose $\Delta G^{\circ}$ is calculated at $1073 \mathrm{~K}$.

$$
\mathrm{MgO}+\mathrm{Al}_{2} \mathrm{O}_{3} \rightarrow \mathrm{MgAl}_{2} \mathrm{O}_{4}, \Delta G^{\circ} 1073 \mathrm{~K}=-92.02 \mathrm{~kJ}
$$

The successive formation of $\mathrm{MgO}$ and $\mathrm{Al}_{2} \mathrm{O}_{3}$ causes expansion and contraction during the reaction, which results in breaking the crystals into numerous smaller crystals, thus producing the porosity required for the diffusion of aluminum, magnesium onwards, or nickel backwards.

Figure 5 shows the variation in the magnesium concentration as a function of the $\mathrm{NiO}$ injection time, and the concentration of magnesium decreased continuously during the injection, reaching the lower value of $1.98 \mathrm{wt}-\%$ at the end of the experiments for the given conditions established. 


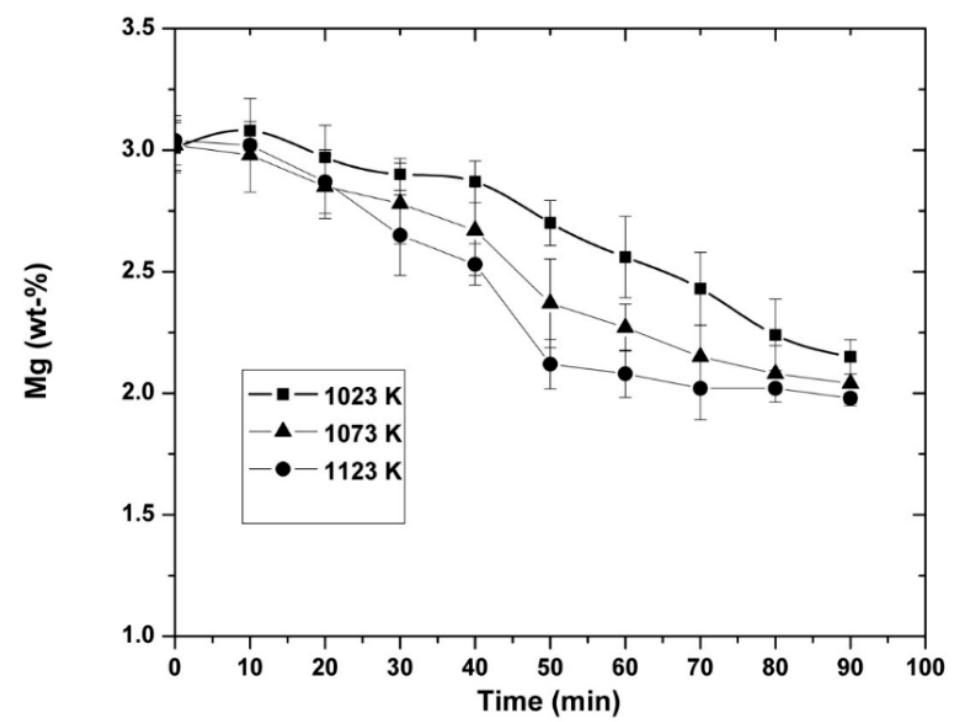

Figure 5. Decrease of the magnesium concentration in molten aluminum as a function of injection time at the indicated temperatures at the constant agitation speed of $300 \mathrm{rpm}$.

The micrographs in Figure 6 show the evolution of the microstructure of the aluminothermic reduction reaction of the $\mathrm{NiO}$ powders as a function of the indicated injection times from samples obtained at $1123 \mathrm{~K}$, at a constant agitation speed of $300 \mathrm{rpm}$. In these micrographs, it was observed that the amount of the nickel-rich intermetallic phase increased as the treatment time increased, therefore the amount of nickel incorporated in the molten alloy increased with increasing time.

Figure 7 shows the increase in the amount of Ni-rich intermetallic phase as a function of the injection time, hence, the amount of nickel incorporated was increased in the molten alloy by the aluminothermic reduction reaction of the $\mathrm{NiO}$ powders.
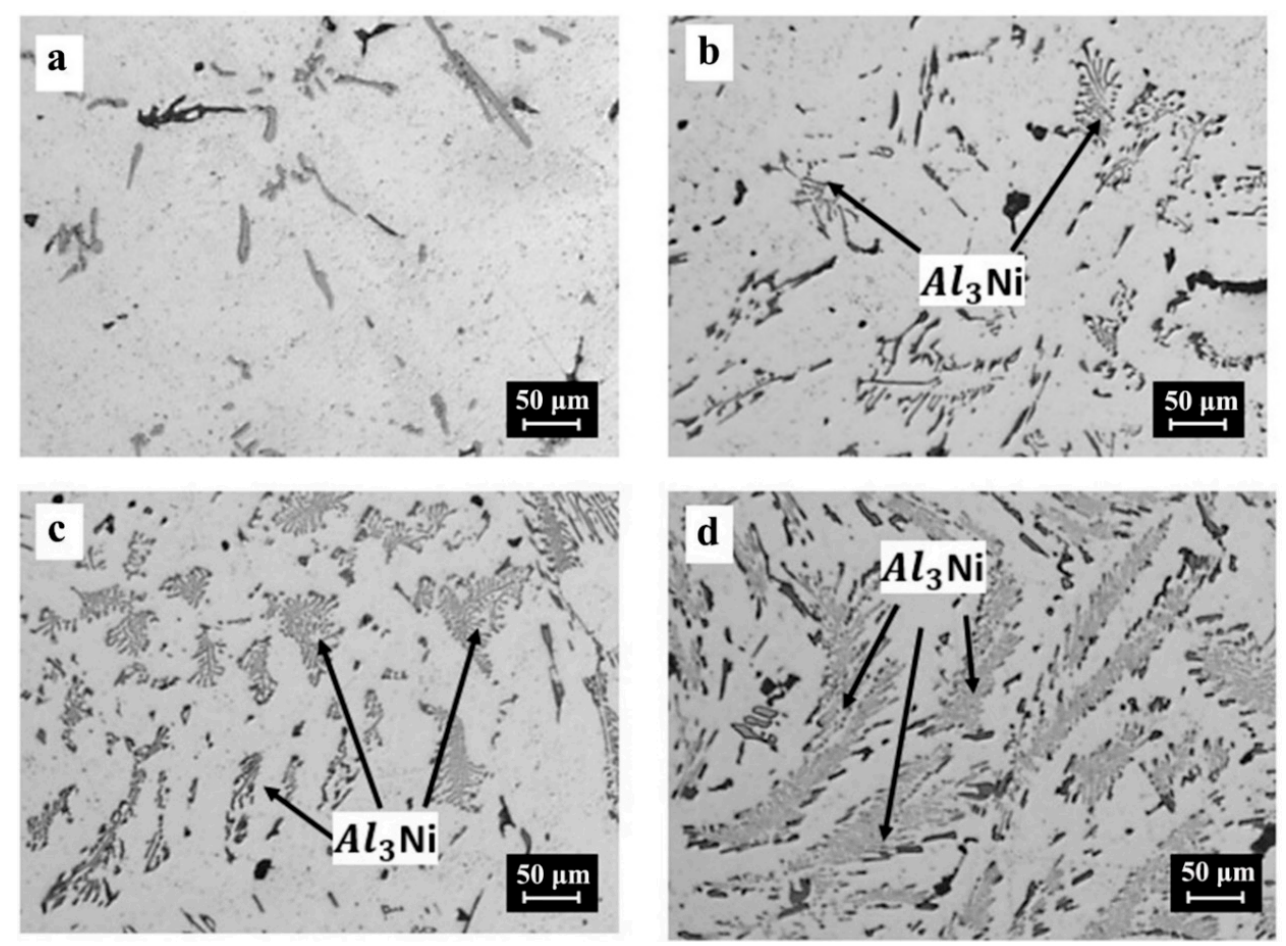

Figure 6. Photomicrographs of Al-Ni samples obtained at $1123 \mathrm{~K}$, as a function of injection time, where (a) $0 \mathrm{~min}$, (b) $20 \mathrm{~min}$, (c) $40 \mathrm{~min}$, and (d) $90 \mathrm{~min}$. 


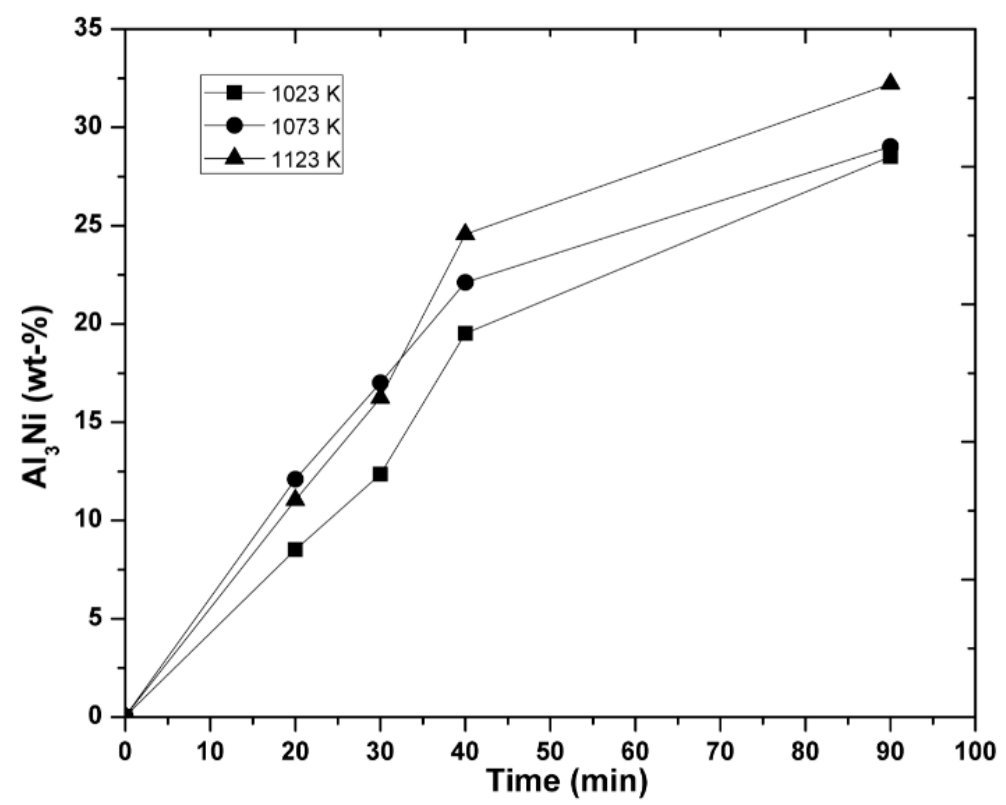

Figure 7. Increase of the $\mathrm{Al}_{3} \mathrm{Ni}$ intermetallic phase as a function of injection time for the temperatures indicated at the constant agitation speed of $300 \mathrm{rpm}$.

The micrographs in Figure 8 show the evolution of the thickness of the layers of the NiO particles reacted as a function of the reaction time, taken from the molten metal at a temperature of $1123 \mathrm{~K}$ for an agitation speed of $300 \mathrm{rpm}$. After $30 \mathrm{~min}$, the particle remained unreacted (Figure 8a), and after 40 min of addition, it began to form an $\mathrm{Al}_{2} \mathrm{O}_{3}$ layer around the $\mathrm{NiO}$ particle (Figure $8 \mathrm{~b}$ ). This layer grew progressively until the reaction stopped because of a change in the mechanism that controls the reaction (Figure $8 \mathrm{c}, \mathrm{d}$ ). After $70 \mathrm{~min}$ of contact (Figure 8e), the $\mathrm{Al}_{2} \mathrm{O}_{3}$ layer began to disappear. In the micrographs, it can be seen that after $90 \mathrm{~min}$ of reaction, the $\mathrm{Al}_{2} \mathrm{O}_{3}$ layer completely disappeared, leaving only the solid particle and the $\mathrm{Al}_{3} \mathrm{Ni}$ intermetallic particles around them.
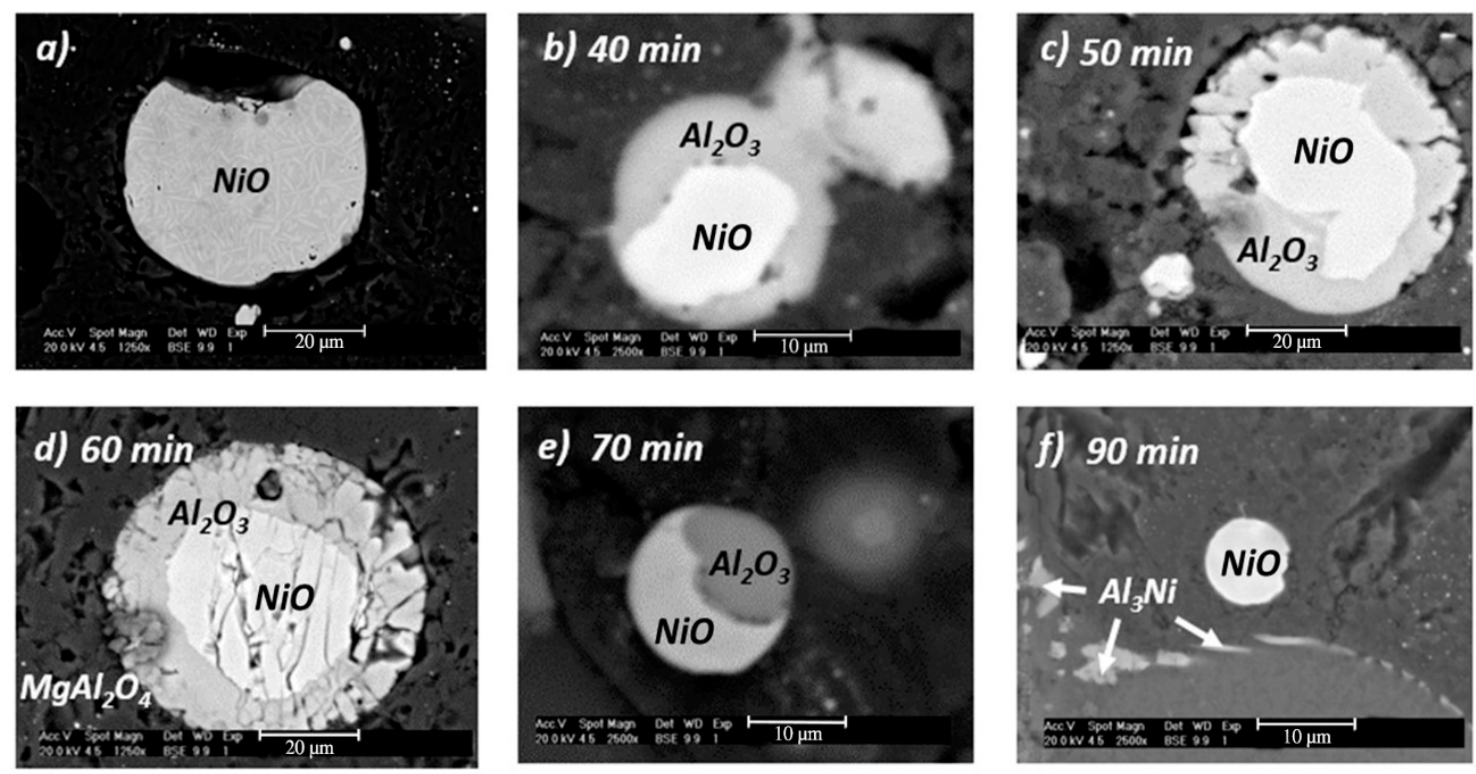

Figure 8. SEM images of partially reacted $\mathrm{NiO}$ particles obtained from molten aluminum at $1123 \mathrm{~K}$ at a stirring speed of $300 \mathrm{rpm}$ for the indicated times of (a) $30 \mathrm{~min}$, (b) $40 \mathrm{~min}$, (c) $50 \mathrm{~min}$, (d) $60 \mathrm{~min}$, (e) $70 \mathrm{~min}$, and (f) $90 \mathrm{~min}$. 
The particle shown in Figure 8d was analyzed separately by energy dispersion spectroscopy in the SEM, and the corresponding energy dispersive X-ray spectroscopy (EDS) patterns, together with the micrographs showing the microareas from where they were obtained, are shown in Figure 9. The microanalysis measurements show that the nucleus of $\mathrm{NiO}$ was surrounded by an $\mathrm{Mg}$ and $\mathrm{Al}$-rich phase, marked as (2) and (3). The semi-quantitative chemical composition of the layer of the reaction product, as shown in Table 5, was observed as the phase formed was spinel $\left(\mathrm{MgAl}_{2} \mathrm{O}_{4}\right)$. These EDS results suggest that the $\mathrm{NiO}$ was reduced by aluminum and magnesium, forming intermediate reaction products such as the spinel phase, while the Ni-rich phase corresponded to $\mathrm{Al}_{3} \mathrm{Ni}$ [26].
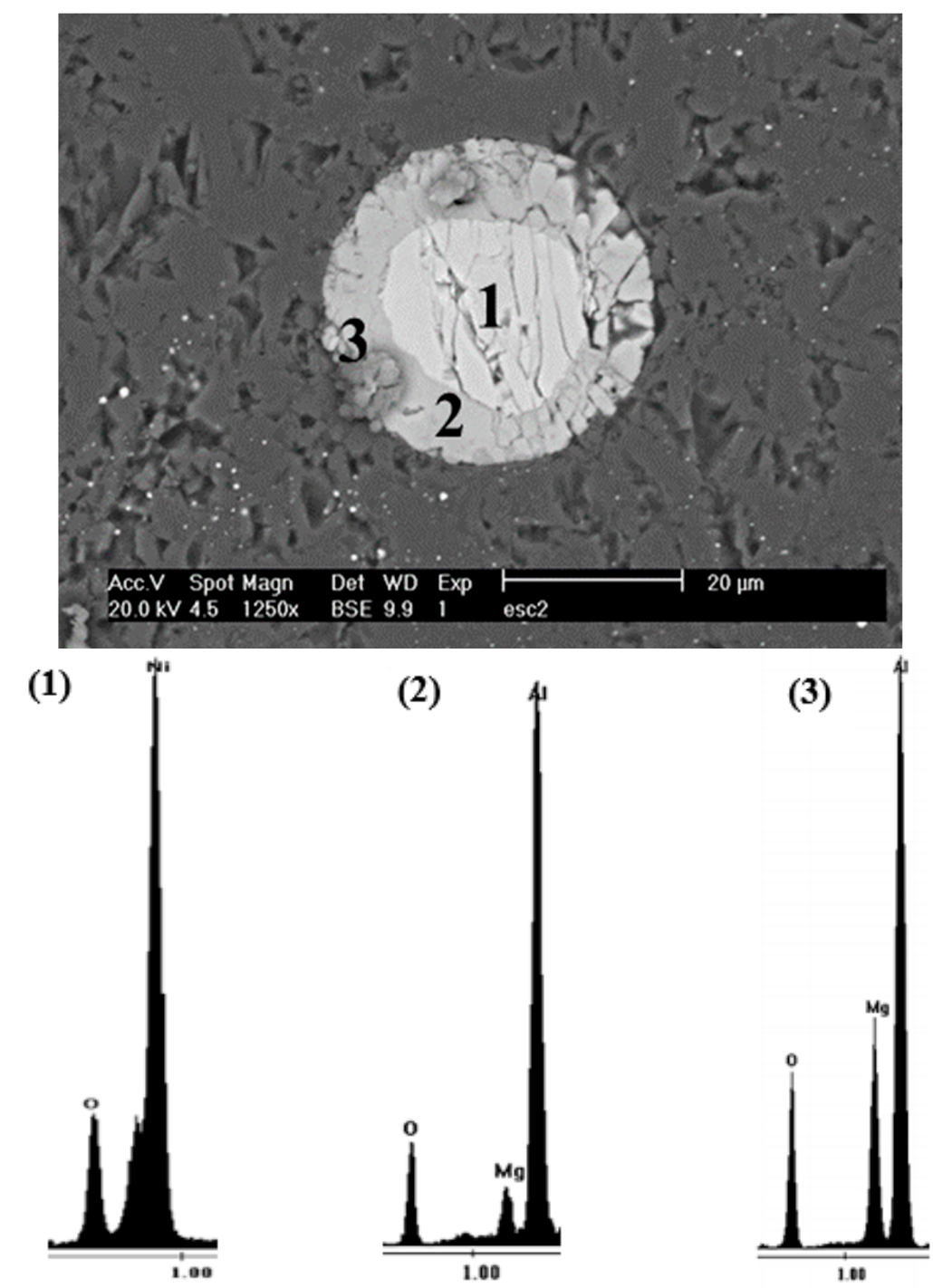

Figure 9. SEM images of the partially reacted $\mathrm{NiO}$ particle shown in Figure 8d, and the corresponding EDS patterns of the microareas of the (1) center, (2) outside layer, and (3) $\mathrm{MgAl}_{2} \mathrm{O}_{4}$.

Table 5. EDS chemical analysis of the partially reacted $\mathrm{NiO}$ particle shown in Figure 8d.

\begin{tabular}{ccccc}
\hline \multirow{2}{*}{ Particle } & \multicolumn{5}{c}{ wt-\% } \\
\cline { 2 - 5 } & $\mathbf{N i}$ & $\mathbf{O}$ & $\mathbf{A 1}$ & $\mathbf{M g}$ \\
\hline 1 & 67.51 & 32.49 & 0 & 0 \\
2 & 0 & 25.76 & 72.14 & 2.1 \\
3 & 0 & 31.45 & 49.79 & 18.76 \\
\hline
\end{tabular}


Figure 10 shows the $\mathrm{X}$-ray powder diffraction (XRD) pattern corresponding to the slag obtained after the end of experiment E27, where there was the presence of $\mathrm{MgO}, \mathrm{MgAl}_{2} \mathrm{O}_{4}$, aluminum, and $\mathrm{NiO}$. The aluminum came from the molten alloy, as the sample was taken from a pasty area formed between the slag and molten aluminum.

The $\mathrm{MgO}$ and $\mathrm{MgAl}_{2} \mathrm{O}_{4}$ in the slag suggests that both aluminum and magnesium reduced the nickel oxide by a metallothermic mechanism. The $\mathrm{NiO}$ came from the partially reacted particles. The analysis of the slag helped to corroborate that the main aluminothermic reduction reaction was that given by Equation (2), where the $\mathrm{Ni}$ was obtained from $\mathrm{NiO}$ dissolved in the molten alloy to solidify as $\mathrm{Al}_{3} \mathrm{Ni}$ particles, which are shown in Figure 5.

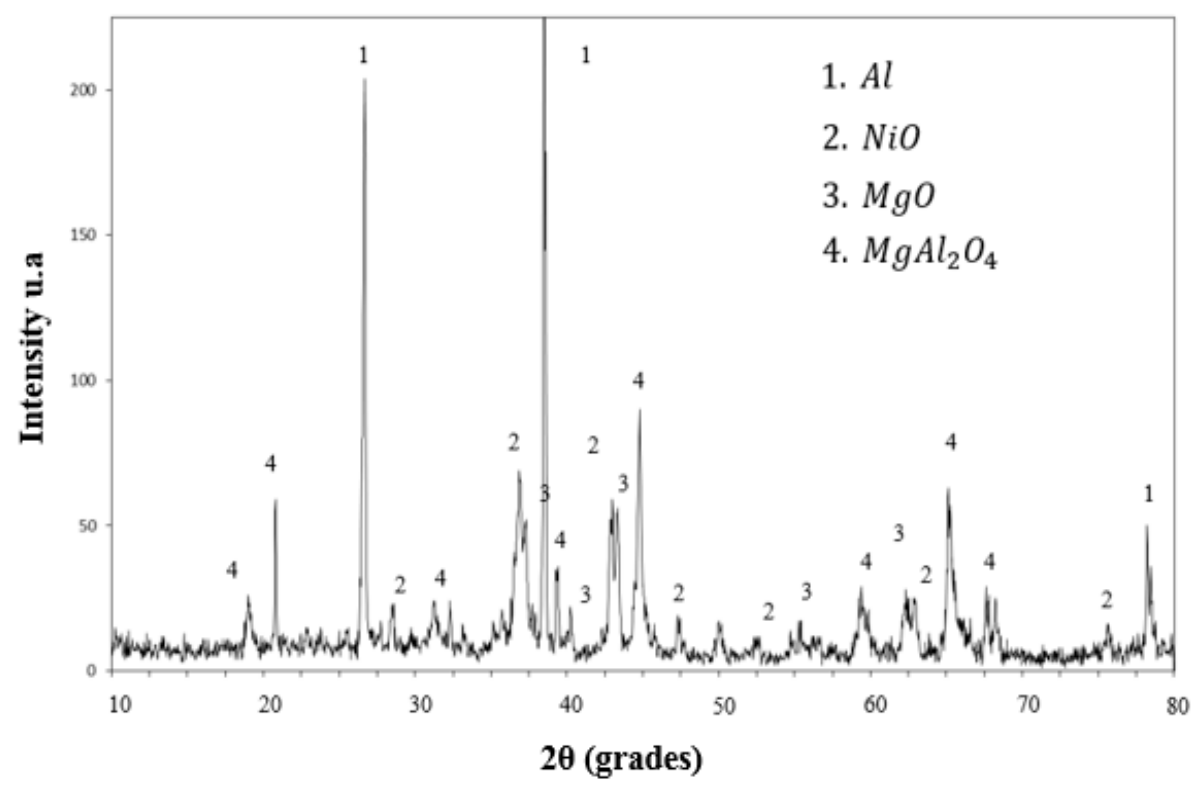

Figure 10. XRD pattern of the slag samples for an alloy where the initial magnesium was $3 \mathrm{wt}-\%$ at a stirring speed of $300 \mathrm{rpm}$ and a temperature of $1123 \mathrm{~K}$.

\subsection{Thermodynamic Consideration for the Al-NiO-Mg System}

The aluminum alloys obtained in this work contained between 2 to 3 wt-\% of both $\mathrm{Mg}$ and $\mathrm{Ni}$, therefore, a thermodynamic explanation would help to understand the expected results. During the aluminothermic reduction process, the $\mathrm{Al}, \mathrm{Mg}$, and $\mathrm{NiO}$ species are involved, and react to obtain different reaction products. The software FactSage allowed us to consider ideal solutions for the $\mathrm{Al}-\mathrm{Mg}-\mathrm{Ni}$ system in the solid and liquid states. The reactants that were introduced into the software were $\mathrm{Al}, \mathrm{Mg}$, and $\mathrm{Ni}$ as pure species. The balance of the system was computerized for the temperature range from 373 to $1273 \mathrm{~K}$, where the activities considered for $\mathrm{Al}, \mathrm{Ni}$, and $\mathrm{Mg}$ were equal to 1 . Figure 11 shows the results of the software in the Al-Mg-Ni equilibrium system. The phases that were present below the melting temperature of aluminum were $\mathrm{Al}(\mathrm{s}), \mathrm{MgO}$, and $\mathrm{Al}_{3} \mathrm{Ni}$ in their stable forms, while at temperatures higher than $933 \mathrm{~K}$, the $\mathrm{Al}$ and $\mathrm{Mg}$ were in a liquid state. These results define the reactions involved during the reduction of $\mathrm{NiO}$ powders by $\mathrm{Al}-\mathrm{Mg}(\mathrm{l})$. The formation of $\mathrm{MgO}$ is thermodynamically feasible from room temperature up to the melting temperature of aluminum. However, the diagram drawn by the software was preliminary as the kinetic conditions change continuously during the reaction. 


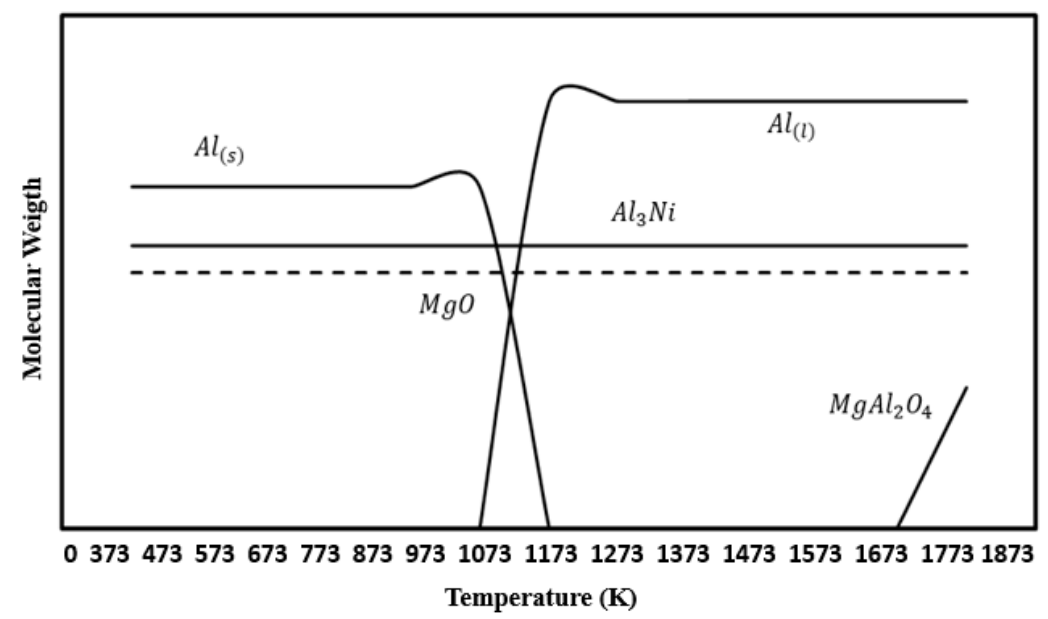

Figure 11. Equilibrium diagram of species for the Al-Mg-NiO system in the temperature range from 373 to $1873 \mathrm{~K}$.

The reactions are presented and the values of $\Delta G^{\circ}$ at $1123 \mathrm{~K}$ were obtained from the software, expressed per mole of oxygen.

$$
4 / 3 \mathrm{Al}+\mathrm{O}_{2}=2 / 3 \mathrm{Al}_{2} \mathrm{O}_{3}, \mathrm{G}^{\circ}{ }_{1123 \mathrm{~K}}=-882.46 \mathrm{~kJ}
$$

Reaction (5) can occur between aluminum and oxygen from the environment with pressures of $1 \mathrm{~atm}$ and elevated temperatures, forming $\mathrm{Al}_{2} \mathrm{O}_{3}$. The next reaction can occur between $\mathrm{Al}_{2} \mathrm{O}_{3}$ with magnesium and oxygen to form the spinel $\mathrm{MgAl}_{2} \mathrm{O}_{4}$, which is possible with amounts higher than $0.05 \% \mathrm{Mg}$.

$$
\mathrm{Al}_{2} \mathrm{O}_{3}+\mathrm{Mg}+1 / 2 \mathrm{O}_{2}=\mathrm{MgAl}_{2} \mathrm{O}_{4}, \Delta \mathrm{G}^{\circ} 1123 \mathrm{~K}=-1036.56 \mathrm{~kJ}
$$

Reactions (5) and (6) must be produced at the aluminum/slag interface, forming a protective layer of aluminum and magnesium oxides in the molten bath.

The reaction between $\mathrm{Al}$ and $\mathrm{NiO}$ to form $\mathrm{Al}_{2} \mathrm{O}_{3}$ while releasing $\mathrm{Ni}$ is quite possible because of the action masses law, as aluminum is the element present in greater quantity in the system. The reaction is that given by Equation (1). However, the graphs in Figure 2 show that in the experiments performed with pure aluminum, the concentration of nickel attained was rather low. It was shown that $\mathrm{Al}_{2} \mathrm{O}_{3}$ [27] in a wide range of temperatures was not wettable by aluminum, because it has a contact angle value $>90.5^{\circ}[28]$.

Therefore, it is necessary to decrease the contact angle of $\mathrm{Al}_{2} \mathrm{O}_{3}$ by molten aluminum. According to the literature [29], one way to change the contact angle is to lower the surface energy of molten aluminum by adding $\mathrm{Mg}$, as this is one of the elements that has this effect.

In the experiments that were carried out, it was observed that the magnesium content decreased with the increased time, as is shown in Figure 5. This was attributed not only to the effect of this element on the contact angle, but also to the high reactivity that magnesium possesses, according to the following reaction:

$$
\mathrm{NiO}+\mathrm{Mg}=\mathrm{MgO}+\mathrm{Ni}, \Delta G^{\circ}{ }_{1123 \mathrm{~K}}=-342.83 \mathrm{~kJ}
$$

The global chemical reaction taking place is that given by Equation (2). The following reaction is possible because of the greater chemical reactivity of $\mathrm{Mg}$ than $\mathrm{Al}$ :

$$
\mathrm{Al}_{2} \mathrm{O}_{3}+3 \mathrm{Mg}=3 \mathrm{MgO}+2 \mathrm{Al}, \Delta G^{\circ} 1123 \mathrm{~K}=-117.69 \mathrm{~kJ}
$$

The formation of $\mathrm{MgO}$, a phase present in the slag produced in this work for aluminum alloys with initial $\mathrm{Mg}$ concentrations above $2 \mathrm{wt}-\%$, proceeded from the following reaction: 


$$
2 \mathrm{Mg}+\mathrm{O}_{2}=2 \mathrm{MgO}, \Delta \mathrm{G}^{\circ} 1123 \mathrm{~K}=-970.09 \mathrm{~kJ}
$$

In turn, $\mathrm{Al}_{2} \mathrm{O}_{3}$ and $\mathrm{MgO}$ react according to Equation (4) to form the so-called spinel, $\mathrm{MgAl}_{2} \mathrm{O}_{4}$.

All of the reaction products described by the reactions given by Equations (1), (2), (4), (5), or (7)-(9) were found in the slags obtained from the $\mathrm{NiO}$ reduction process studied in this work.

\subsection{Kinetic Measurements}

The experimental evidence strongly indicated that the reaction rate in the studied process was controlled by the diffusion of chemical species, mainly $\mathrm{Al}$ or $\mathrm{Mg}$, to the boundary layer, where they reacted with $\mathrm{NiO}$. Consequently, the experimental information obtained at each temperature, for alloys with and without magnesium, was analyzed using the kinetic formulas presented by Brown [30]. However, to adapt to the experimental information of the available kinetic models, it was assumed that the observed nickel concentration corresponded to that of the complete reaction, and therefore, the final reacted fraction was equal to 1 . First of all, it is necessary to state that for the present case, the reaction rate is defined as the ratio of the reacted fraction $(\alpha)$ against time $(t)$, given by the following:

$$
\text { reaction rate }=\frac{d \alpha}{d t}
$$

As an associated magnitude to the progress of the aluminothermic reaction, $\alpha$ is numerically equal to the reacted fraction attained in a given period, called actual time. Therefore, reacted fraction, in our case $\alpha_{N i}$, is given by next equation:

$$
\alpha_{N i}=\frac{w_{o}-w_{i}}{w_{o}-w_{f}}
$$

where $w_{0}, w_{i}$, and $w_{f}$ are the $N i$ concentrations measured in the alloy at the beginning of the injection time, the actual concentration, and the final concentration, respectively.

Figures 12-14 show the change in the reacted fraction as a function of time, for the different set of parameters studied, resulted from the application of Equation (11) to the experimental results obtained. In general, it can be observed from these graphs that the aluminothermic reduction reaction was not completed for any value of the parameters studied (i.e., temperature, initial magnesium concentration, or agitation speed), owing to the diffusive nature of the reaction, as it will be explained later.

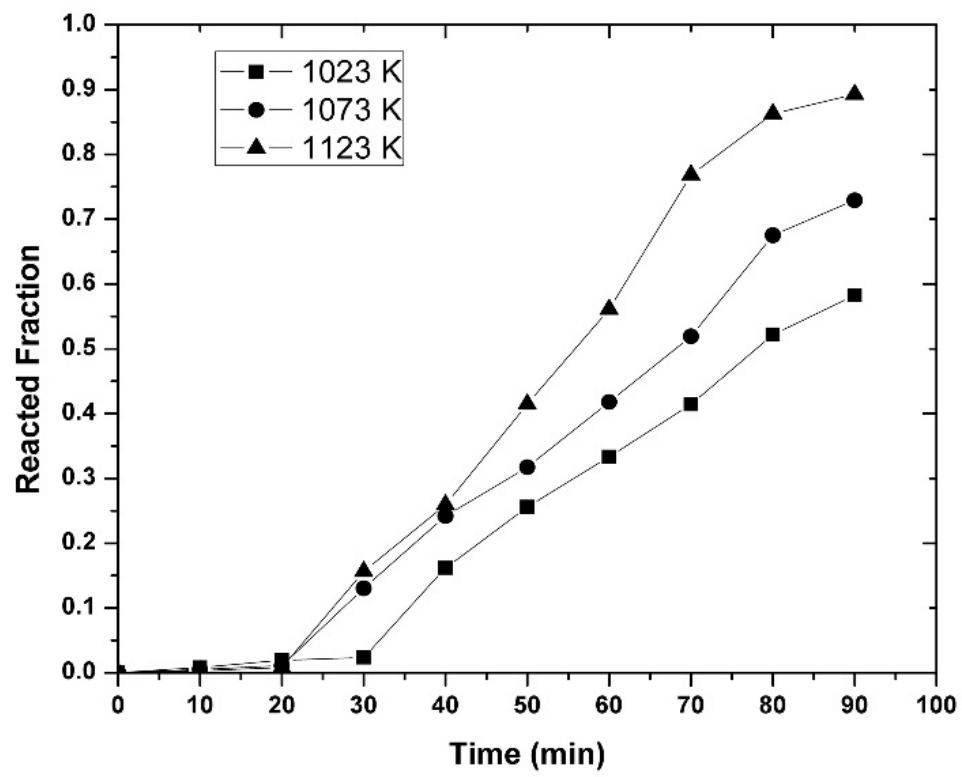

Figure 12. Reacted fraction of $\mathrm{Ni}$ as a function of time for the temperatures indicated, for a constant initial concentration of $\mathrm{Mg}$ of $3 \mathrm{wt}-\%$, at the constant agitation speed of $300 \mathrm{rpm}$. 


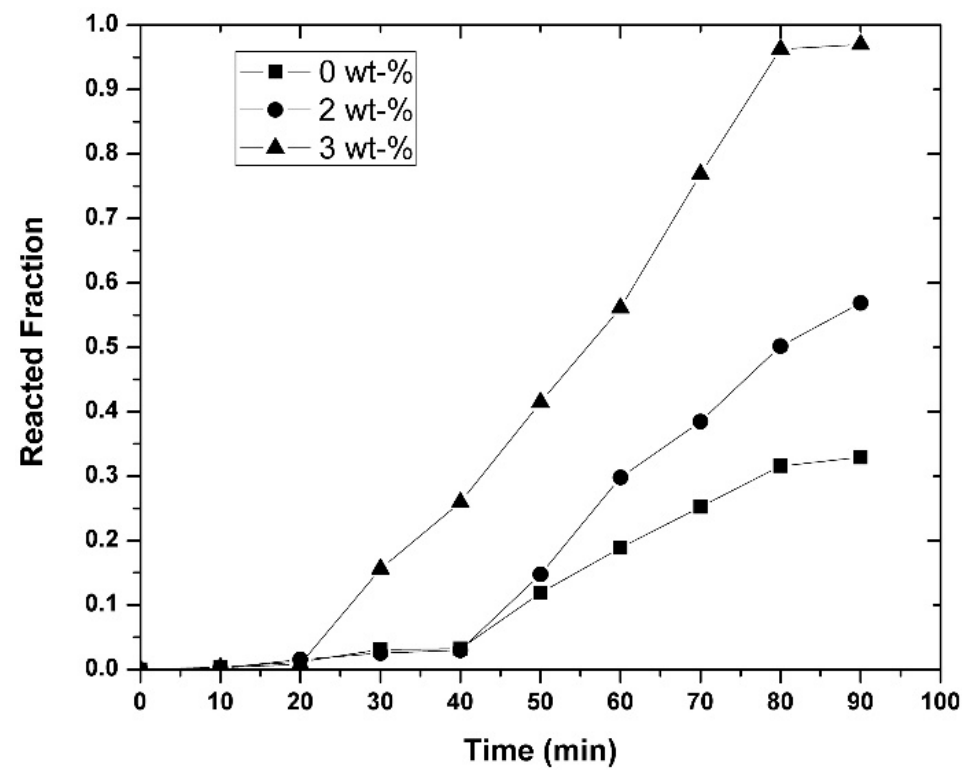

Figure 13. Reacted fraction of $\mathrm{Ni}$ as a function of time for the initial magnesium concentrations indicated, at the constant temperature of $1123 \mathrm{~K}$, and constant agitation speed of $300 \mathrm{rpm}$.

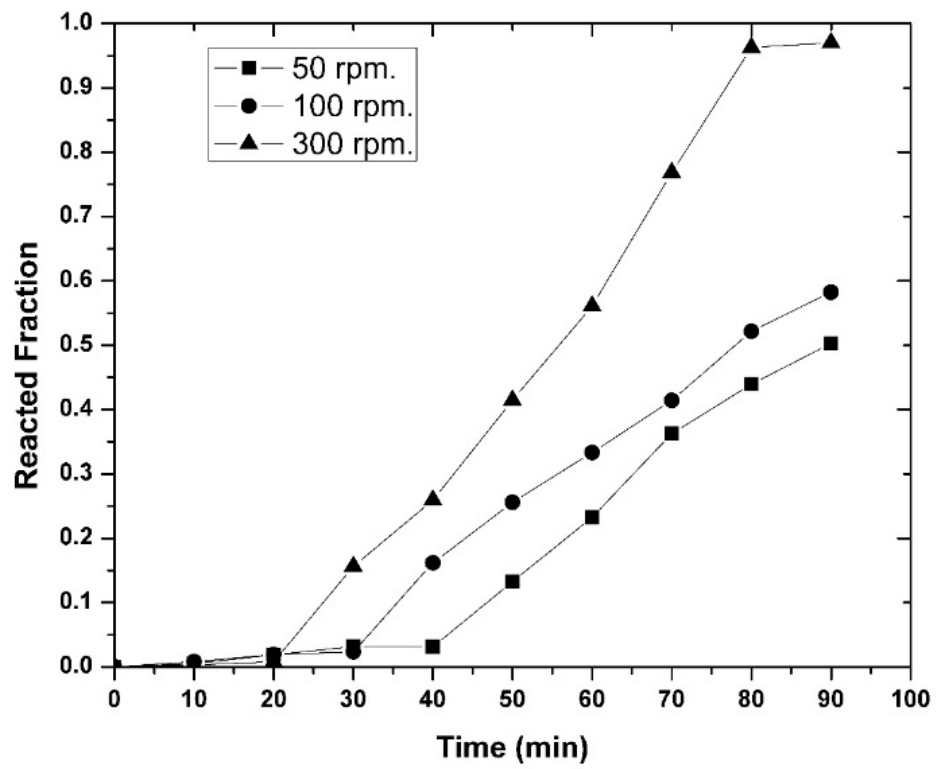

Figure 14. Reacted fraction of $\mathrm{Ni}$ as a function of time for the agitation speed indicated, for a constant initial concentration of $\mathrm{Mg}$ of $3 \mathrm{wt}-\%$, at the constant temperature of $1123 \mathrm{~K}$.

In this sense, it was found that the kinetic information was well suited for the diffusion model equation (D1), as shown in Figure 15, which corresponded to the experiments where alloys with magnesium were used at an agitation speed of $300 \mathrm{rpm}$. In turn, Figure 16 shows the experimental results at different temperatures. The equation of the model is as follows:

$$
(1-\alpha) \ln (1-\alpha)+\alpha
$$

where $\alpha$ is the reacted fraction. 


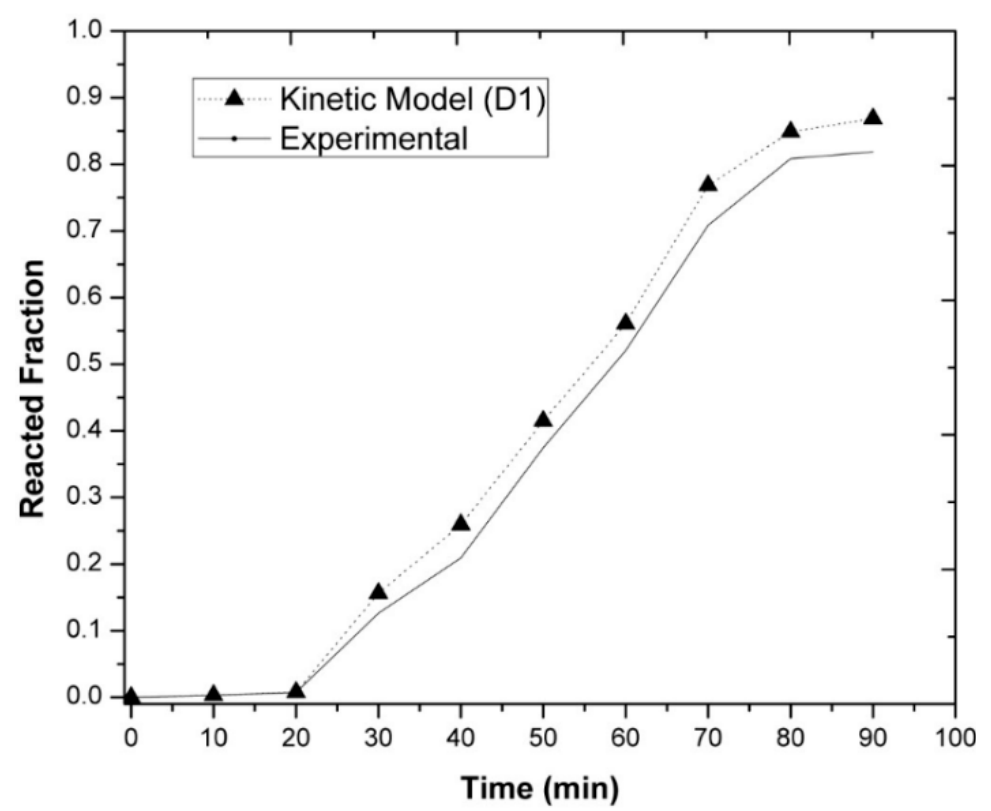

Figure 15. Experimental results and prediction of model D1 at the temperature of $1123 \mathrm{~K}$ for an alloy with $3 \mathrm{wt}-\% \mathrm{Mg}$ at $300 \mathrm{rpm}$.

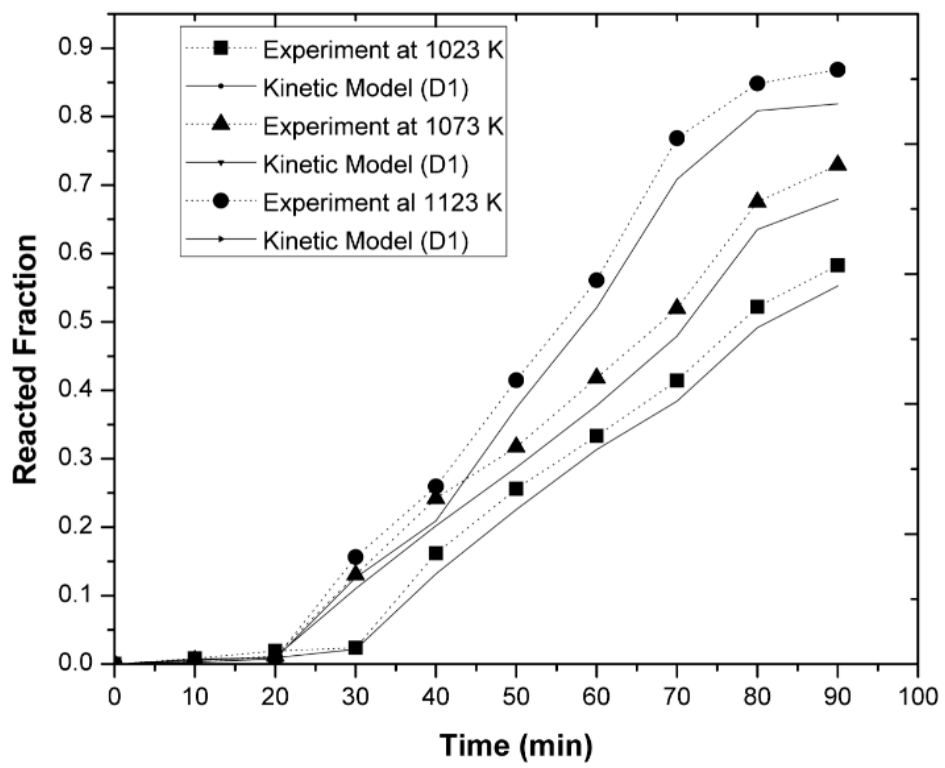

Figure 16. Experimental results and prediction of the D1 model at different temperatures for alloys with an initial $\mathrm{Mg}$ concentration of $3 \mathrm{wt}-\%$, at $300 \mathrm{rpm}$.

The linear regression of $\ln (k)$ against $1 / T$ was plotted to obtain the values of the activation energy and the rate constants using the Arrhenius equation given below:

$$
k=k_{0} e^{-E / R T}
$$

where $E$ is the activation energy $\left(\mathrm{J} \mathrm{mol}^{-1}\right)$, and $R$ is the universal gas constant $\left(8.314 \mathrm{~J} \mathrm{~mol}^{-1} \mathrm{~K}\right)$. Figure 17 shows the linear dependence of a graph of $\ln (k)$ against $1 / T$ for the aluminothermic reduction of $\mathrm{NiO}$ for alloys with magnesium (a) and without magnesium (b). From the slope values of these graphs, the values of the activation energies were determined as $E=35.75 \mathrm{KJ} \mathrm{mol}^{-1}$ for the alloys 
without magnesium and $E=15.80 \mathrm{KJ} \mathrm{mol}^{-1}$ for the alloys with an initial magnesium concentration of $3 \mathrm{wt}-\% \mathrm{Mg}$.

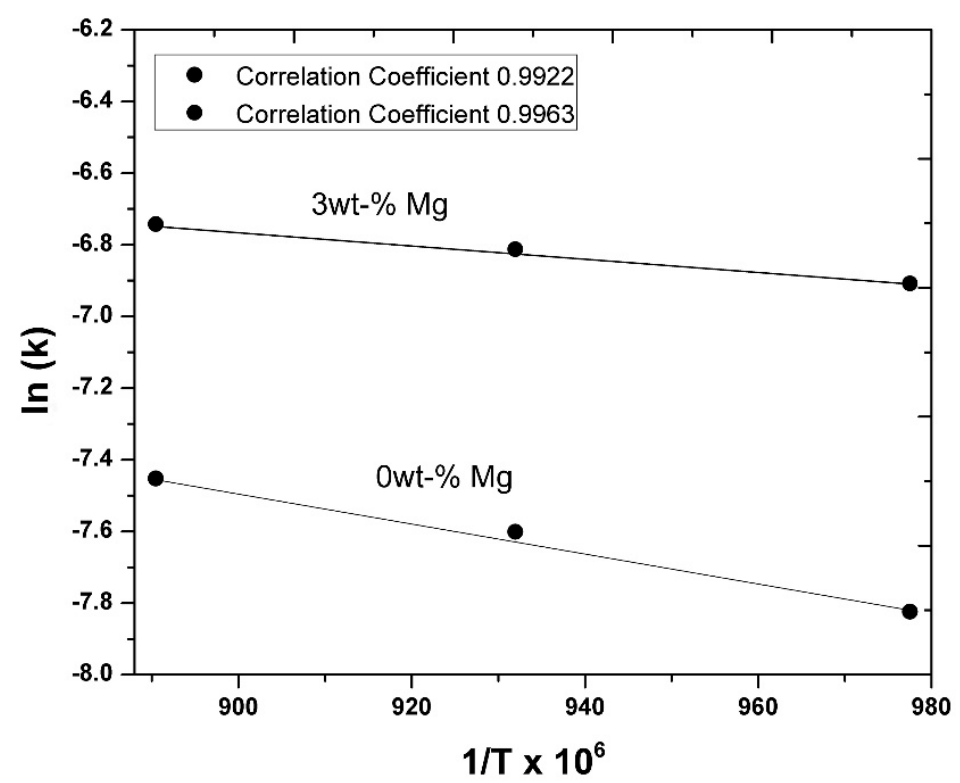

Figure 17. Graphs of $\ln (k)$ against $1 / T$ for the determination of the activation energy for the recovery of nickel with magnesium were 0 and $3 \mathrm{wt}-\%$.

From the values of the kinetic parameters determined in this section, it can be stated that, as expected, the higher values of the rate constants indicated that the reaction rate was improved by the presence of magnesium in the alloys, at least initially. This occurred because, for reaction times greater than $70 \mathrm{~min}$, the reaction tends to stop. According to the observations in the micrographs of the partially reacted particles, it can be stated that this occurred through the formation of a thin layer of reaction products around the $\mathrm{NiO}$ particles. In addition, the activation energy for the aluminothermic reduction reaction of the $\mathrm{NiO}$ particles when using alloys with $3 \mathrm{wt}-\%$ by weight of magnesium, was lower than that of the experiments when no $\mathrm{Mg}$ was added.

\subsection{Mechanism of Reaction}

Regarding the reaction mechanisms that operate during the aluminothermic reduction reaction of $\mathrm{NiO}$ powders, the most precise explanation is that given by Zhong et al. [31], who stated that the formation of $\mathrm{MgAl}_{2} \mathrm{O}_{4}$ depends strongly on the initial concentration of magnesium, as has been previously established thermodynamically and has been experimentally proven in this work. Therefore, for initial magnesium concentrations of around $1 \mathrm{wt}-\%$, the stable phase is $\mathrm{MgAl}_{2} \mathrm{O}_{4}$. Mcleod and Gabryel [32] established that the presence of $\mathrm{MgO}$ occurred because of the high initial concentration of magnesium ( $>3 \mathrm{wt}-\%)$. However, this concentration was easily reached at the $\mathrm{NiO}$ interface, especially in the initial stages after the addition of the particles, which ensured the formation of a significant amount of $\mathrm{MgO}$. On the other hand, most of the $\mathrm{MgO}$ was consumed by the $\mathrm{MgAl}_{2} \mathrm{O}_{4}$ formation reaction given by Equation (4). Molins et al. [33] studied the interfacial reaction between a molten AlMg alloy and $\mathrm{Al}_{2} \mathrm{O}_{3}$ fibers, where it was shown that the $\mathrm{MgO}$ nuclei remained small and formed thin layers of $\sim 10 \mu \mathrm{m}$ thick. Therefore, the diffusion of magnesium occurred through the grain boundaries of the $\mathrm{MgO}$ particles by means of an infiltration mechanism. The growth process of the MgO layers continued until the grains around the matrix/reaction zone interface were large enough to close the intergranular spaces. The Gibbs free energy reaction of Equation (2) indicated that the reduction of $\mathrm{NiO}$ by aluminum occurred because $\mathrm{Al}$ can diffuse through the spaces left by the backwards diffusion of $\mathrm{Ni}$. The diffusion of nickel occurred through the grain boundaries of $\mathrm{MgO}$ and $\mathrm{Al}_{2} \mathrm{O}_{3}$, dissolving 
in the molten aluminum when it reached the outer interface. Upon solidification, the nickel was rejected from the solid solution, forming $\mathrm{Al}_{3} \mathrm{Ni}$ crystals around the partially reacted $\mathrm{NiO}$ particles. When the stoichiometric amounts of $\mathrm{MgO}$ and $\mathrm{Al}_{2} \mathrm{O}_{3}$ formed and equilibrium conditions occurred, the reaction given by Equation (2) was carried out. In this way, the formation of $\mathrm{MgO}$ and $\mathrm{Al}_{2} \mathrm{O}_{3}$ and the interdiffusion of $\mathrm{Al}, \mathrm{Mg}$, and $\mathrm{Ni}$ occurred simultaneously. After the magnesium concentration in the molten alloy fell below $1.98 \mathrm{wt}-\%$, the aluminum continued to react with the $\mathrm{NiO}$ cores to form additional $\mathrm{Al}_{2} \mathrm{O}_{3}$ at a constant growth rate controlled by the diffusion of the aluminum through the layers of the reaction products. On the other hand, the small amount of $\mathrm{MgO}$ that could be formed by the magnesium reaction with $\mathrm{NiO}$ was dissolved in the $\mathrm{Al}_{2} \mathrm{O}_{3}$ phase. The reactions between the molten aluminum and magnesium dissolved with solid $\mathrm{NiO}$ require the diffusion of the atoms, although the diffusion of oxygen is negligible due to its large ionic size.

Therefore, the interdiffusion of magnesium and aluminum is kinetically possible through the network in the $\mathrm{NiO}$ structure of the $\mathrm{O}$ atoms, or through the nickel that results from the decomposition of the NiO. When the magnesium atoms occupy the interstitial sites within the NiO network, the position of the oxygen atoms must be adjusted to maintain electrical neutrality and to decrease the distortion energy of the network. Such reactions were given by the following:

$$
\begin{gathered}
\mathrm{Mg}^{0}-2 \mathrm{e}^{-}=\mathrm{Mg}^{+2} \\
2\left(\mathrm{Al}^{0}-3 \mathrm{e}^{0}\right)=2 \mathrm{Al}^{+3} \\
4\left(\mathrm{Ni}^{+3}-3 \mathrm{e}^{-}\right)=4 \mathrm{Ni}^{0}
\end{gathered}
$$

The result is a change in the crystalline structure. The process involved in this phenomenon is governed by the values of the chemical potential of the partial reactions given, in this case, by Reactions (1) and (2). As $\mathrm{MgAl}_{2} \mathrm{O}_{4}$ is the final reaction product at room temperature, the reaction given by the global Equation (2) can be accepted, as this reaction satisfies the described mechanism. A necessary kinetic condition for the diffusion of chemical species is that the porosity remains in the layers of the reaction products. For similar reduction chemical reactions in molten aluminum, Zhong et al. [31] determined that the formation of $\mathrm{MgO}_{\text {on }} \mathrm{SiO}_{2}$ particles involved a volume contraction of $13.6 \%$, while the formation of $\mathrm{MgAl}_{2} \mathrm{O}_{4}$ on $\mathrm{SiO}_{2}$ particles caused a volume contraction of $27 \%$. Due to these changes in volume, the newly formed phases instantly broke their junctions with the original particles and transformed into thousands of small crystals. This transformation produces the necessary voids for the diffusion of the chemical species. However, for the last stages of the reduction process, the reduction mechanism changed abruptly, as the concentration of magnesium in the reaction interface decreased to below $1.98 \mathrm{wt}-\%$. At this time, the $\mathrm{MgO}$ that was formed dissolved in $\mathrm{Al}_{2} \mathrm{O}_{3}$. Then, these $\mathrm{Al}_{2} \mathrm{O}_{3}$ crystals grew continuously until they reached a micrometric size, which resulted in the blocking of spaces for diffusion and the chemical reaction begins to stop. In this last stage, the efficiency of the reaction decreased sharply. The above explanations are important from the technological point of view, as unreacted $\mathrm{NiO}$ particles can be trapped in the molten metal as inclusions, and thus also affect the efficiency of the reaction. Of course, the kinetics of the reaction can be accelerated by further decreasing the size of the $\mathrm{NiO}$ particles or imposing the mixing conditions in the turbulent flow regime by using Reynolds numbers above $4.5 \times 10^{3}$ to break the layers of the reaction products once they have formed [34].

Figure 18 shows a schematic representation of the proposed mechanism of reaction, which described the different stages and the reactions among the participant chemical species, corresponding to a situation where the temperature was constant at $1123 \mathrm{~K}$, initial magnesium concentration was constant at $3 \mathrm{wt}-\%$, and agitation speed is constant at $300 \mathrm{rpm}$. 
(a)

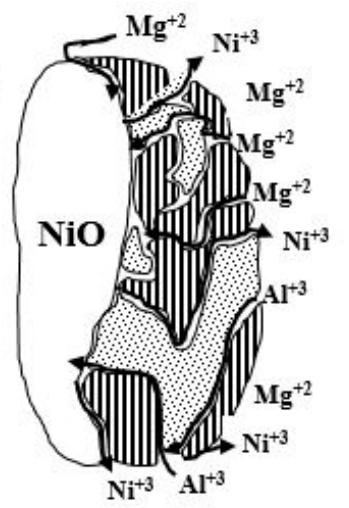

(c)

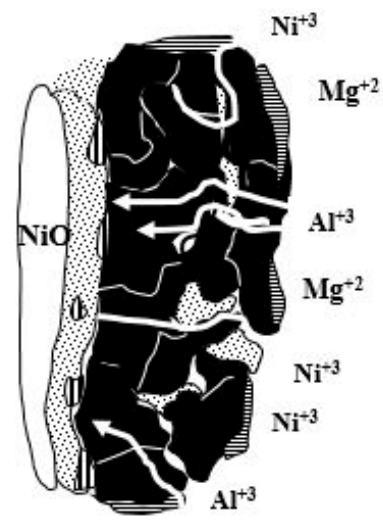

(b)

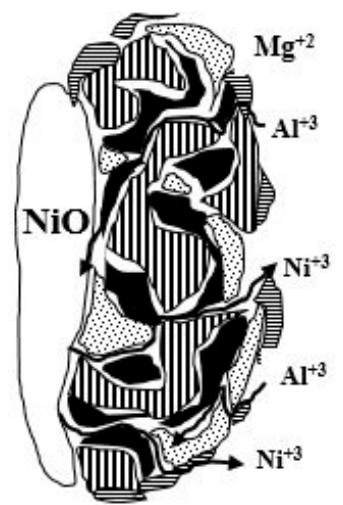

(d)

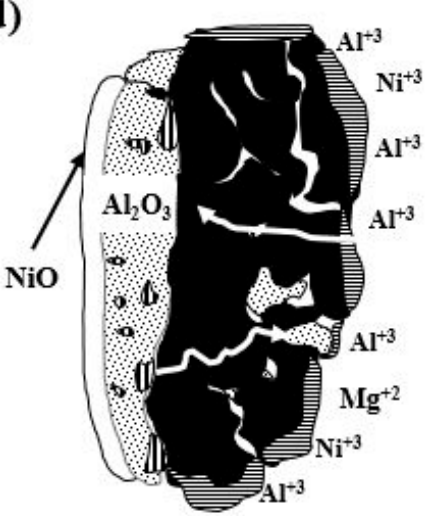

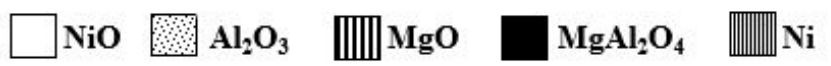

Figure 18. Scheme of the mechanism of reaction proposed for the permanent contact reaction between dissolved magnesium in molten aluminum and $\mathrm{NiiO}$ particles; (a) instantaneous formation of $\mathrm{MgO}$ and $\mathrm{Al}_{2} \mathrm{O}_{3}, 10 \mathrm{~min}$; (b) $\mathrm{MgAl}_{2} \mathrm{O}_{4}$ formation, $40 \mathrm{~min}$; (c) nickel diffusion to the molten alloy, $70 \mathrm{~min}$; (d) and consolidation of the layers of reaction products consisting of $\mathrm{MgAl}_{2} \mathrm{O}_{4}$ separated by layers of the $\mathrm{Al}_{2} \mathrm{O}_{3}$ phase, $90 \mathrm{~min}$.

\section{Conclusions}

1. The aluminothermic reduction of $\mathrm{NiO}$ was studied at a laboratory scale by means of the powder injection technique, assisted by mechanical agitation, and achieved an increase in the nickel concentration in the solidified alloys of up to $3 \mathrm{wt}-\%$ for some of the experiments carried out.

2. It was observed that increasing the temperature favored the increase in the nickel concentration, because the mechanisms that govern the kinetics of the process, diffusion to the boundary layer, diffusion inside the layers of reaction products, and chemical reaction, were thermally activated. Increasing the mixing conditions by increasing the stirring speed of the molten bath using mechanical agitators at the velocity of $300 \mathrm{rpm}$ promoted a greater agitation, therefore improving the efficiency of the reaction.

3. Increasing the initial magnesium concentration in the molten alloy allowed the Ni concentration to increase in the alloys, as was thermodynamically and experimentally demonstrated.

4. The experimentally obtained values of the Ni concentration as a function of time for different values of the parameters investigated (temperature, agitation speed, or initial $\mathrm{Mg}$ concentration) were adjusted to the kinetic equation of the diffusion model, which adjusted reasonably well. This allowed us to determine the values of some kinetic parameters of interest. On the other hand, the activation energy of the processes based on the Arrhenius equation was determined to be $15.80 \mathrm{KJ} \mathrm{mol}^{-1}$ for alloys containing an initial amount of $3 \mathrm{wt}-\% \mathrm{Mg}$. 
5. With respect to the reaction mechanism, it was found that the step that controlled the overall chemical reaction was the diffusion of the $\mathrm{Al}$ and $\mathrm{Mg}$ atoms to the boundary layer, where they reacted with $\mathrm{NiO}$ particles, releasing $\mathrm{Ni}$ and forming $\mathrm{Al}_{2} \mathrm{O}_{3}$ and $\mathrm{MgO}$ as the reaction products. In turn, these compounds formed $\mathrm{MgAl}_{2} \mathrm{O}_{4}$ during cooling. The formation and breaking of $\mathrm{MgAl}_{2} \mathrm{O}_{4}$ into many crystals ensured the porosity required for the diffusion of the chemical species involved.

Author Contributions: Investigation, C.S.B. and R.O.P.; supervision, A.F.V. and J.T.T.

Funding: This research was funded by Fundicion J.V. with the project 217843 of the program Stimulus to the Investigation of CONACYT Mexico.

Acknowledgments: The authors wish to acknowledge the financial support of Fundicion J.V., project 217843 of the program Stimulus to the Investigation of CONACYT México, as well as for the cast shop facilities provided through this project.

Conflicts of Interest: The authors declare no conflicts of interest.

\section{References}

1. López, L.N.; Fernandes, H.; Gutiérrez, A.; Sánchez, J.A. Turning of thick thermal spray coatings. J. Therm. Spray Technol. 2001, 10, 249-254.

2. Beranoagirre, A.; Lopez de Lacalle, L.N. Optimising the milling of titanium aluminide alloys. Int. J. Math. Math. Sci. 2010, 3, 425-436. [CrossRef]

3. Priarone, P.C.; Klocke, F.; Giulia, M.; Lung, D.; Settineri1, L. Tool life and surface integrity when turning titanium aluminides with PCD tools under conventional wet cutting and cryogenic cooling. Int. J. Adv. Manuf. Technol. 2016, 85, 807-816. [CrossRef]

4. Beranoagirre, A.; Olvera, D.; López de Lacalle, L.N. Milling of gamma titanium-aluminum alloys. Int. J. Adv. Manuf. Technol. 2012, 62, 83-88. [CrossRef]

5. Quintana, R.; Perdomo, L.; Cruz, A.; Gomez, L.; Garcia, L.L.; Cerpa, A.; Cores, A. Obtención simultanea de ferroaleación multicomponente y escoria a partir de arenas negras, para el desarrollo de consumibles de soldadura por arco eléctrico. Rev. Metal. 2004, 40, 294-303. [CrossRef]

6. Ai, D.; Liu, K.; Lu, Z.; Zou, M.; Zeng, D.; Jun, M. Aluminothermal synthesis and characterization $\mathrm{Li}_{3} \mathrm{~V}_{2}$-xAlx $\left(\mathrm{PO}_{4}\right)_{3}$ cathode materials for lithium ion batteries. Electrochim. Acta 2011, 56, 2823-2827. [CrossRef]

7. Muñiz, R.; Flores, A.; Torres, J. A kinetic study of the strontium extraction by metallothermic reduction using submerged SrO powders injection. Mater. Lett. 2008, 62, 637-640. [CrossRef]

8. Luna, S.; Flores, A.; Muñiz, R.; Fernández, A.; Torres, J.; Rodriguez, N.; Ortíz, J.C.; Orozco, P. Cerium extraction by metallothermic reduction using cerium oxide powder injection. J. Rare Earths 2011, 29, 74-77. [CrossRef]

9. Flores, A.; Juárez, R.; Torrres, J.; Ayala, Z. A kinetic study on the aluminothermic reduction of $\mathrm{ZrO}_{2}$. J. Eng. Technol. 2012, 2, 17-22.

10. Guía, J.C. Estudio de la Reducción Metalotérmica de Una Mezcla de $\mathrm{Fe}_{3} \mathrm{O}_{4}-\mathrm{Cr}_{2} \mathrm{O}_{3}$ para la Obtención de Fe-C. Master's Thesis, CINVESTAV-Saltillo, Ramos Arizpe, Mexico, 2010.

11. Ochoa, R.M. Utilización de Electrodos de Baterías Alcalinas Descargadas como Materia Prima para la Elaboración de Aleaciones Al-Zn-Mg y Al-Mn'. Master's Thesis, CINVESTAV Saltillo, Ramos Arizpe, Mexico, 2009.

12. Udhayabanu, V.; Singh, N.; Murty, B.S. Mechanical activation of aluminothermic reduction of $\mathrm{NiO}$ by high energy ball milling. J. Alloys Compd. 2010, 497, 142-146. [CrossRef]

13. López, F.J. Estudio Termodinámico y Cinético de la Reducción de $\mathrm{SrCO}_{3}$ por Al Bajo Condiciones de Vacío. Master's Thesis, CINVESTAV Saltillo, Ramos Arizpe, Mexico, 2006.

14. Muñiz, C.R. Estudio del Proceso de Elaboración de Aleaciones Maestras Al-Si-Sr Mediante la Inyección de Polvos de $\mathrm{SrCO}_{3}$. Ph.D. Thesis, CINVESTAV Saltillo, Ramos Arizpe, Mexico, 2008.

15. Zhao, K.; Feng, N.; Wang, Y. Fabrication of Ti-Al intermetallics by a two-stage aluminothermic reduction process using $\mathrm{Na}_{2} \mathrm{TiF}_{6}$. Intermetallics 2017, 85, 156-162. [CrossRef] 
16. La, P.; Li, Z.; Li, C.; Hu, S.; Lu, X.; Wei, Y.; Wei, F. Effect of substrates on microstructure and mechanical properties of nano-eutectic 1080 steel produced by aluminothermic reaction. Mater. Charact. 2014, 92, 84-90. [CrossRef]

17. Mishra, K.; Zheng, J.; Patel, R.; Estevez, L.; Jia, H.; Luo, L.; Khoury, P.E.; Li, X.; Zhou, X.D.; Zhang, J.G. High performance Si@C anodes synthesized by low temperature aluminothermic reaction. Electrochim. Acta 2018, 269, 509-516. [CrossRef]

18. Liu, F.G.; Wen, C.D.; Hu, X.W.; Gao, B.L.; Shi, Z.N.; Wang, Z.W. Preparation of aluminum-zirconium master alloy by aluminothermic reduction in cryolite melt. JOM 2017, 69, 2644-2647. [CrossRef]

19. Malekia, A.; Hosseini, N.; Niroumand, B. A review on aluminothermic reaction of $\mathrm{Al} / \mathrm{ZnO}$ system. Ceram. Int. 2018, 44, 10-23. [CrossRef]

20. Ochoa, R.; Flores, A.; Torres, J. Effect of magnesium on the aluminothermic reduction rate of zinc oxide obtained from spent alkaline battery anodes for the preparation of Al-Z-Mg alloys. J. Int. Miner. Metall. Mater. 2016, 23, 458-465. [CrossRef]

21. HSC Chemistry Software, Version 6.12. Outotec. 2007. Available online: https://www.outotec.com (accessed on 9 July 2018).

22. Thermochemical Software and Data Base System, Version 6.1. FactSage. 2009. Available online: http: / /www.factsage.com/ (accessed on 9 July 2018).

23. Guedes, M.; Ferreira, J.M.; Ferro, A.C. A study on $\mathrm{CuO}-\mathrm{Al}_{2} \mathrm{O}_{3}$ infiltration by aluminium. Mater. Sci. Forum 2010, 636-637, 571-577. [CrossRef]

24. Langlais, J.; Harris, R. Strontium extraction by aluminothermic reduction. Can. Metall. Q 1991, 31, $127-131$. [CrossRef]

25. Pai, B.C.; Ray, S. Fabrication of aluminum-alumina (magnesia) particulate composites in foundries using magnesium additions to melts. Mater. Sci. Eng. A 1976, 24, 31-44. [CrossRef]

26. Gul, F.; Karakulak, E.; Yamanoglu, R.; Zeren, M. Mechanical properties of Al-Ni Cast alloys. In Proceedings of the 23rd International Conference on Metallurgy and Materials, Brno, Czech Republic, 21-23 May 2014; pp. 1283-1287.

27. Bergsmark, E.; Simensen, C.J.; Kofstad, P. The oxidation of molten aluminum. Mater. Sci. Eng. A 1989, 120-121, 91-95. [CrossRef]

28. Ochoa, R. Relación Microestructura-Propiedades Mecánicas de las Aleaciones Al-Zn-Mg-Cu y Al-Zn-Mg-Cu-1\% Li Elaboradas por Reducción Aluminotérmica del Ánodo de Pilas Alcalinas Descargadas y Latas para Bebidas. Ph.D. Thesis, CINVESTAV Saltillo, Ramos Arizpe, Mexico, 2016.

29. Allaire, C. Furnaces: Improving low cement castable by non-wetting additives. JOM 2001, 53, $24-27$.

30. Brown, M.E.; Gallagher, P.K. Handbook of Thermal Analysis and Calorimetry; Elsevier: London, UK, 2008; pp. 148-149.

31. Zhong, W.M.; L'Espérance, G.L.; Suery, M. Interfacial reactions in Al-Mg (5083)/SiC $p$ composites during fabrication and remelting. Metall. Mater. Trans. A 1995, 26, 2625-2635. [CrossRef]

32. Mcleod, A.D.; Gabryel, C.M. Kinetics of the growth of spinel, $\mathrm{MgAl}_{2} \mathrm{O}_{4}$, on alumina particulate in aluminum alloys containing magnesium. Metall. Mater. Trans. A 1992, 23, 1279-1283. [CrossRef]

33. Molins, R.; Bartout, J.D.; Bienvenu, Y. Microstructural and analytical characterization of $\mathrm{Al}_{2} \mathrm{O}_{3}-(\mathrm{Al}-\mathrm{Mg})$ composite interfaces. Mater. Sci. Eng. A 1991, 135, 111-117. [CrossRef]

34. Dimotakis, P.E. The mixing transition in turbulent flows. J. Fluid. Mech. 2000, 409, 69-98. [CrossRef]

(C) 2018 by the authors. Licensee MDPI, Basel, Switzerland. This article is an open access article distributed under the terms and conditions of the Creative Commons Attribution (CC BY) license (http://creativecommons.org/licenses/by/4.0/). 